Kurniadie, D. • V. Putri · U. Umiyati

\title{
Hubungan kualitas air tercemar dengan keragaman gulma air di Daerah Aliran Sungai Cikeruh dan Cikapundung Provinsi Jawa Barat
}

\section{The relationship between contaminated water quality and weed diversity in Cikeruh and Cikapundung rivers}

Diterima : 15 November 2016/Disetujui : 15 Desember 2016 / Dipublikasikan : 30 Desember 2016

CDepartment of Crop Science, Padjadjaran University

\begin{abstract}
The research was conducted from May to August with the aim to determine the diversity of aquatic weeds and relationships presence of aquatic weeds that grow on river basin and watershed Cikapundung Cikeruh West Java with contaminated water quality agricultural waste, residential waste and industrial waste. Methods of weed survey research methods to cluster sampling on vegetation communities in the upstream, midstream, and downstream. The result of the research showed that dominant weed in Cikeruh upstream area is Drymaria cordata $(L)$, in the Cikeruh midstream and downstream area is Eleusine indica $(L)$, while the dominant weed in Cikapundung upstream area is $D$. cordata $(L)$, in the Cikapundung midstream area is Ageratum conyzoides ( $L)$, and in the Cikapundung downstream area is Cyperus difformis (L)es. A value of C Cikeruh and Cikapundung area is less than $75 \%$ or there is no similarity population, while the value of $\mathrm{H}^{\prime}$ included in low category, and the value of $\mathrm{E}$ included in medium category. There is no correlation between diversity of weeds with water quality in Cikeruh and Cikapundung area.
\end{abstract}

Keywords: Contaminated · Diversity of weed . Weed domination

Sari Penelitian dilaksanakan pada bulan Mei sampai Agustus dengan tujuan untuk mengetahui keragaman gulma air dan hubungan keberadaan gulma air yang tumbuh pada DAS Cikeruh dan DAS Cikapundung Propinsi Jawa Barat dengan kualitas air yang tercemar limbah pertanian, limbah pemukiman, dan limbah

\footnotetext{
Dikomunikasikan oleh Tien Turmuktini

Kurniadie, D. · V. Putri · U. Umiyati

Agroteknologi Department, Agriculture Faculty,

Padjadjaran University

Jl. Raya Bandung-Sumedang km. 21 Jatinangor-Jawa Barat

Korespondensi e-mail: denny.kurniadie@gmail.com
}

industri. Metode penelitian metode weed survey dengan cluster sampling diletakkan pada komunitas vegetasi di daerah hulu, tengah, dan hilir sungai. Hasil penelitian menunjukkan bahwa gulma dominan tumbuh di sungai Cikeruh adalah : Drymaria cordata $(L)$, daerah tengah dan hilir adalah: Eleusine indica $(L)$, sedangkan gulma di DAS Cikapundung bagian hulu adalah Drymaria cordata $(L)$, daerah tengah dan hilir adalah Ageratum conyzoides (L), dan Cyperus difformis $(L)$. Nilai C sungai Cikeruh dan sungai Cikapundung menunjukkan lebih kecil dari 75 $\%$ atau tidak terdapat kesamaan populasi, sedangkan nilai $\mathrm{H}^{\prime}$ termasuk dalam kategori rendah, dan nilai $\mathrm{E}$ termasuk dalam kategori sedang. Tidak terdapat korelasi antara keragaman jenis gulma dengan kualitas air di DAS Cikeruh dan DAS Cikapundung.

Kata Kunci : Dominasi gulma · Pencemaran · Keragaman gulma air

\section{Pendahuluan}

Sungai mempunyai kawasan tampungan air yang akan masuk ke badan sungai yang dinamakan daerah aliran sungai (DAS) yang dibagi menjadi tiga bagian, yaitu DAS bagian hulu, tengah, dan hilir (Bisri, 2009). Secara umum, DAS dapat didefinisikan sebagai suatu wilayah yang dibatasi oleh batas alam, seperti punggung bukit atau gunung, maupun batas buatan seperti jalan atau tanggul (Suripin, 2002).

Kondisi DAS Cikeruh saat ini telah mengalami banyak perubahan, sehingga kualitas airnya kurang layak dimanfaatkan untuk kehidupan sehari-hari. Banyak limbah pertanian, rumah tangga, dan industri yang di buang begitu saja ke aliran sungai tanpa pengolahan terlebih dahulu, menjadikan air sungai banyak sampah 
dan tercemar. Demikian pula dengan DAS Cikapundung telah mengalami pencemaran air yang tinggi, bersumber dari pertambahnya jumlah penduduk, perumahan dibantaran sungai, Industri dan alih fungsi lahan pertanian ke nonpertanian (Matahelumual, 2010).

Limbah yang dibuang ke DAS Cikeruh dan Cikapundung berbeda-beda jumlah dan jenisnya, sehingga berpengaruh terhadap kualitas air masing-masing sungai. Kualitas air sungai akan menentukan pertumbuhan keanekaragaman gulma air. Gulma cenderung tumbuh lebih subur di daerah hulu sungai (karena daerah pertanian) dibandingkan daerah hilir (karena daerah industri), hal ini dimungkinkan karena sebagian besar unsur hara yang berasal dari pupuk organik dan anorganik akan terakumulasi di bagian hulu sungai, sehingga dapat merangsang laju pertumbuhan beberapa jenis gulma air seperti Eichornia crassipes (Mart.) Solms, Azolla pinata R. Br, dan Hydrilla verticillata (L) (boleh sebutkan lagi yang lainnya (Edward, 1981). Menurut Halim (2010), pertumbuhan gulma air dapat mempercepat kehilangan air melalui evapotranspirasi, pendangkalan sungai, tersumbatnya aliran sungai bahkan dapat mengurangi produksi ikan di rawa-rawa ataupun di danau.

\section{Bahan dan Metode}

Penelitian dilaksanakan pada bulan Mei sampai Agustus 2014 di DAS Cikeruh dan DAS Cikapundung Provinsi Jawa Barat. Metode penelitian menggunakan metode weed survey dengan cluster sampling diletakkan pada komunitas vegetasi di daerah hulu, tengah, dan hilir DAS yang dialiri air yang tercemar limbah pertanian, limbah pemukiman, dan limbah industri. DAS Cikeruh bagian hulu terletak di daerah Baru Beureum, Desa Sindang Sari, Kecamatan Jatinangor, bagian tengah terletak di Desa SayangKecamatan Jatinangor, sedangkan bagian hilir terletak di daerah Babadolan. Desa DangdeurKecamatan Rancaekek, Kabupaten Bandung. DAS Cikapundung bagian hulu terletak di Maribaya, Desa Cibodas, Kecamatan Lembang, Kabupaten Bandung Barat, bagian tengah terletak di Babakan Siliwangi Kota Bandung, sedangkan bagian hilir terletak di daerah Bojongsoang Kabupaten Bandung. Alat yang digunakan dalam penelitian adalah: alat analisa kualitas air seperti : termos es, dissolved oxygen meter ; konduktivitimeter; spektrophotometer;
pH meter untuk meng-analisa Derajat Keasaman $(\mathrm{pH})$; kamera, alat-aat lapang untuk mengambil dokumentasi, dan alat tulis.

Parameter yang diukur pada gulma air dihitung berdasarkan rumus Tjitrosoedirdjo, $d k k$. (1984) meliputi: rumus yang dipakai disesuaikan dengan parameter yang diukur pada penelitian ini saja.

Kerapatan mutlak suatu jenis $=$ Jumlah individu suatu jenis dalam kelompok yang dilalui oleh rintisan

Kerapatan nisbi suatu jenis

$=\frac{\text { Kerapatan mutlak suatu jenis }}{\text { Kerapatan mutlak semua jenis }} \times 100 \%$

Frekuensi mutlak suatu jenis $=$ $\frac{\text { Jumlah rintisan yang memuat suatu jenis }}{\text { Jumlah rintisan }} \times 100 \%$

Frekuensi nisbi suatu jenis $=$ $\frac{\text { Frekuensi mutlak suatu jenis }}{\text { Frekuensi mutlak seluruh jenis }} \times 100 \%$

Dominansi mutlak suatu jenis $=$ Jumlah panjang semua interval rintisan yang memuat jenis itu

Dominansi nisbi suatu jenis $=$ $\frac{\text { Dominansi mutlak suatu jenis }}{\text { Dominansi mutlak seluruh jenis }} \times 100 \%$

Nilai penting $=$

(Kelindungan nisbi + frekuensi nisbi + dominansi nisbi)

SDR (Summed Dominance Ratio) $=\frac{\text { Nilai penting }}{3}$

$$
C=\frac{2 \mathrm{~W}}{a+b} \times 100 \%
$$

Dimana : $\mathrm{C}=$ Koefisien komunitas; $\mathrm{W}=$ Jumlah dari dua kuantitas terendah untuk jenis dari masing-masing komunitas; $\mathrm{a}=$ Jumlah dari seluruh kuantitas pada komunitas pertama; $b=$ Jumlah dari seluruh kuantitas pada komunitas kedua.

Indeks Keanekaragaman Spesies $\left(\mathrm{H}^{\prime}\right)$ dengan program Ecological Methodology $2^{\text {nd }}$ Edition, nilai $\mathrm{H}^{\prime}$ biasanya berkisar dari 0-7. menurut (Barbour, Burk, dan Pitts (1987) dalam Agustina (2008) dengan rumus

$$
\mathrm{H}^{\prime}=\Sigma(p i)(\operatorname{In} p i)
$$

Dimana: $p i=\mathrm{ni} / \mathrm{N} ; \mathrm{ni}=$ Jumlah nilai penting satu spesies; $\mathrm{N}=$ Jumlah nilai penting seluruh spesies; $\ln =$ Logaritme natural 
Indeks Kemerataan Spesies (E) menurut Barbour, Burk, dan Pitts (1987) dalam Agustina (2008) menggunakan rumus:

$$
\mathrm{E}=\frac{\mathrm{H}^{\prime}}{\mathrm{Hmax}} \text { atau } \mathrm{E}=\frac{\mathrm{H}^{\prime}}{\operatorname{Ln} \mathrm{S}}
$$

Dimana: $H \max =\mathrm{Ln}$ S; $\mathrm{H}^{\prime}=$ Indeks

Keanekaragaman Spesies; $S=$ Jumlah spesies

Hubungan antara populasi jenis gulma air dengan berbagai unsur dari kualitas air sungai digunakan analisis korelasi dengan persamaan sebagai berikut :

$\mathrm{R}=\sum\left(\mathrm{Y}_{1}-\tilde{\mathrm{Y}}\right)\left(\mathrm{U}_{\mathrm{t}}-\tilde{\mathrm{U}}\right) /\left[(\mathrm{n}-1) \mathrm{S}_{1} \mathrm{~S}_{2}\right]$

$S_{1}=\left[\sum\left(U_{t}-\tilde{U}_{t}\right)^{2} /(n-1)\right]^{1 / 2}$

$S_{1}=\left[\sum\left(Y_{t}-\tilde{Y}_{t}\right)^{2} /(n-1)\right]^{1 / 2}$

\section{Hasil dan Pembahasan}

Keadaan Air Sungai Cikeruh dan Cikapundung. Hasil pengamatan visual kondisi air di daerah sungai Cikeruh dan sungai Cikapundung (Tabel 1) menunjukkan hasil yang berbeda, hal ini dimungkinkan karena buangan limbah yang mengalir ke aliran sungai bagian hulu, tengah dan hilir di dominasi oleh kondisi lingkungan DAS yang beda seperti adanya area pertanian, pemukiman dan industri. Kondisi air di bagian hulu sungai Cikeruh dan sungai Cikapundung tampak bersih, jernih, dan tidak berbau, sehingga airnya banyak dimanfaatkan untuk aktivitas pertanian dan lain sebagainya, lain halnya dengan bagian hilir, relatif tidak dapat dimanfaatkan karena tercemar dari akumulasi dari buangan limbah pertanian, pemukiman dan industri, airnya berwarna hitam pekat, keruh, memiliki bau yang menyengat, dan terdapat timbunan sampah. Selaras dengan pendapat Pujiastuti, dkk. (2013), bahwa kekeruhan memiliki korelasi positif dengan padatan tersuspensi, yaitu semakin tinggi nilai kekeruhan maka semakin tinggi pula nilai padatan tersuspensi.
Kualitas air sungai Cikeruh dan sungai Cikapundung. Berdasarkan hasil pengujian kualitas air pada Tabel 2, dibandingkan dengan standar baku mutu menunjukkan bahwa kualitas air sungai Cikeruh daerah hulu, tengah, dan hilir masih tergolong baik, karena hasil analisis berada di bawah standar baku mutu, begitu juga dengan sungai Cikapundung di daerah hulu dan tengah, namun di daerah hilir sungai Cikapundung menunjukkan kualitas air yang lebih buruk dibandingkan dengan daerah lainnya, hal ini dikarenakan nilai $\mathrm{BOD}_{5}$ yaitu 28,00 mg/L berada jauh di atas standar baku mutu yaitu $12 \mathrm{mg} / \mathrm{L}$. Tingginya nilai $\mathrm{BOD}_{5}$ adalah akibat buangan limbah industri pada daerah hilir memiliki bau yang menyengat, air sungai berwarna hitam pekat, keruh, terdapat buih, serta terdapat tumpukan sampah di pinggiran tepi sungai. Kualitas air bagian hilir adalah akumulasi pencemaran air dari industri dan pencemaran dari bagian hulu dan tengah berupa campuran dari limbah pertanian dan pemukiman. Menurut Happy, dkk. (2012), nilai $\mathrm{BOD}_{5}$ tinggi seperti yang terdapat di daerah hilir sungai Cikapundung dapat menyebabkan menurunnya kadar DO di daerah tersebut, hal ini dikarenakan buruknya lingkungan sungai, banyak-terdapat kotoran dan sampah organik maupun non organik di aliran sungai tersebut.

Pujiastuti, dkk. (2013) menyatakan bahwa, kekeruhan pada suatu perairan tidak selalu menunjukkan kandungan $\mathrm{BOD}_{5}$ dan $\mathrm{COD}$ yang tinggi, tetapi dapat disebabkan oleh endapan atau partikel-partikel suspensi seperti tanah liat, lumpur, bahan-bahan organik terlarut, bakteri, plankton dan organisme lainnya. Kekeruhan biasanya terdiri dari partikel anorganik yang berasal dari erosi DAS dan tersuspensi sedimen di dasar perairan. Kekeruhan memiliki korelasi positif dengan padatan tersuspensi, yaitu semakin tinggi nilai kekeruhan maka semakin tinggi pula nilai padatan tersuspensi.

Tablel 1. Keadaan Air Sungai Cikeruh dan Cikapundung , 2014.

\begin{tabular}{llll}
\hline \hline Lokasi DAS & Warna & Aroma & Sampah \\
\hline Cikeruh & & & Kondisi DAS \\
Hulu & Bening,coklat muda & Tidak berbau & Tidak ada sampah \\
Tengah & Coklat tua, abu-abu & Sedikit menyengat & Ada sampah \\
Hilir & Hitam pekat-keruh & Bau menyengat berbuih & Banyak sampah \\
Cikapundung & & & \\
Hulu & Sedikit bening-coklat tua & Tidak berbau & tidak ada \\
Tengah & Abu-abu- coklat tua & Sedikit menyengat & Ada sampah \\
Hilir & Keruh-hitam pekat & Bau menyengat & Banyak sampah \\
\hline \hline
\end{tabular}


Tabel 2. Hasil Uji Analisa Kualitas Air Sungai Cikeruh dan Sungai Cikapundung 2014.

\begin{tabular}{|c|c|c|c|c|c|c|c|c|}
\hline \multirow[t]{2}{*}{ Parameter } & \multirow{2}{*}{$\begin{array}{l}\text { Nilai } \\
\text { Baku } \\
\text { Mutu }\end{array}$} & \multicolumn{3}{|c|}{$\begin{array}{c}\text { Hasil Analisis } \\
\text { Air Sungai Cikeruh }\end{array}$} & \multicolumn{3}{|c|}{$\begin{array}{c}\text { Hasil Analisis Air } \\
\text { Sungai-Cikapundung }\end{array}$} & \multirow[t]{2}{*}{ Metoda Acuan } \\
\hline & & Hulu & Tengah & Hilir & Hulu & Tengah & Hilir & \\
\hline \multicolumn{9}{|l|}{ Fisika } \\
\hline $\begin{array}{l}\text { Daya Hantar Listrik (DHL) } \\
(\mathrm{mmhos} / \mathrm{Cm})\end{array}$ & - & 103,00 & 230,00 & 136,00 & 321,00 & 427,00 & 143,00 & SNI 06-6989.1-2004 \\
\hline \multicolumn{9}{|l|}{ Kimia } \\
\hline Amonia $\left(\mathrm{NH}_{3}-\mathrm{N}\right)(\mathrm{mg} / \mathrm{L})$ & - & 0,04 & 0,86 & 2,49 & 0,08 & 0,10 & 2,69 & SNI 06-6989.30-2005 \\
\hline $\mathrm{BOD}_{5}(\mathrm{mg} / \mathrm{L})$ & 12 & 0,20 & 4,20 & 0,20 & 2,20 & 1,20 & 28,00 & SNI 6989.72:2009 \\
\hline COD (mg/L) & 100 & $<0,56$ & 12,71 & $<0,56$ & 4,27 & 2,11 & 49,46 & SNI 6989.2:2009 \\
\hline Derajat Keasaman $(\mathrm{pH}, \mathrm{mg} / \mathrm{L})$ & $5,0-9,0$ & 7,70 & 6,70 & 7,18 & 6,85 & 7,59 & 6,96 & SNI 06-6989.11-2004 \\
\hline Nitrat $\left(\mathrm{NO}_{3}-\mathrm{N}\right)(\mathrm{mg} / \mathrm{L})$ & 20 & 1,16 & 3,74 & 4,82 & 2,74 & 3,53 & 11,53 & SNI 6989.79:2011 \\
\hline Oksigen Terlarut (DO, mg/L) & $>0$ & 4,80 & 3,20 & 4,50 & 3,50 & 4,80 & 2,80 & Potensiometri \\
\hline
\end{tabular}

Standar Baku Mutu berdasarkan :PP No 82 Tahun 2001 Kelas IV tentang Pengelolaan Kualitas Air dan Pengendalian Pencemaran Air

Sumber: Laboratorium Pengendalian Kualitas Lingkungan PDAM Tirtawening Kota Bandung (2014)

Hasil analisis kualitas air ternyata nilai $\mathrm{BOD}_{5}$, COD, DO, dan $\mathrm{pH}$ di daerah hulu sungai Cikeruh dan Cikapundung hampir sama, tetapi nilai DHL, Amonia $\left(\mathrm{NH}_{3}-\mathrm{N}\right)$ dan Nitrat $\left(\mathrm{NO}_{3}-\mathrm{N}\right)$ daerah hilir sungai Cikapundung lebih tinggi dibandingkan daerah hilir sungai Cikeruh, hal ini dimungkinkan karena kandungan zat yang terlarut lebih tinggi kuntitas dan kualitasnya. Limbah buangan ini umumnya berasal dari limbah pertanian, perumahan yang terakumulasi dengan limbah buangan industri. Pendapat ini didukung oleh Pujiastuti, dkk. (2013) bahwa kandungan nitrat yang tinggi pada perairan kemungkinan disebabkan oleh tingginya kandungan zat yang terlarut pada daerah hilir dan terjadinya dekomposisi sedimen atau senyawa-senyawa organik yang berasal dari jasad flora dan fauna yang mati. Kandungan nitrat yang tinggi pada perairan juga kemungkinan disebabkan oleh pencemaran akibat pemupukan, kotoran hewan, manusia dan industri. Ammonia pada perairan disebabkan dari nitrogen organik dan nitrogen anorganik yang terdapat dalam tanah dan air yang di dekomposisi bahan organik oleh mikroba dan jamur.

Identifikasi Gulma di DAS Cikeruh dan DAS Cikapundung. Hasil pengamatan identifikasi gulma air pada Tabel 3, menunjukkan bahwa terdapat perbedaan variasi gulma yang berada di DAS Cikeruh dan Cikapundung. Perbedaan ini mungkin disebabkan oleh buangan limbah yang berbeda-beda ke kedua aliran sungai tersebut. Berdasarkan identifikasi gulma air di DAS Cikeruh, bagian hulu, tengah dan hilir masing-masing ditemukan 24, 28 dan 22 jenis gulma air. Di DAS-Cikapundung bagian hulu, tengah dan hilir, masing-masing ditemukan 15, 21 dan 9 jenis gulma air.
Berdasarkan Tabel 3. Ternyata nilai SDR (Summed Dominance Ratio) DAS Cikeruh tertinggi ditampilkan oleh gulma Eleusine indica (L) $(17,19$ \%). Di daerah hulu adalah Drymaria cordata (L) $(11,51 \%)$, Monochoria vaginalis (Burm.f) $(11,12 \%)$, dan Ludwigia perennis (L) (11,35\%). Di daerah tengah adalah Eleusine indica (L) (12,37\%) Euphorbia hirta (L) $(10,51 \%)$, E. indica (L) $(17,19)$, Alternanthera philoxeroides (Mart.) (12,23 \%), dan Amaranthus viridis (L) (11,26 \%). Bervariasinya dominasi gulma air dimungkinkan karena lingkungan abiotik yang berbeda disetiap DAS, hal ini didukung oleh Sastroutomo (1990), yang menyatakan bahwa dominansi gulma pada suatu daerah ditentukan oleh lingkungan tumbuh seperti kualitas air, suhu, iklim dan topografi yang sudah tidak mendukung lagi untuk pertumbuhan beberapa gulma.

Berdasarkan nilai SDR (Summed Dominance Ratio) pada Tabel 3, ternyata pada DAS Cikapundung tertinggi ditunjukkan oleh gulma air Cyperus difformis (L) (20,34 \%). Di daerah hulu adalah Drymaria cordata (L) (12,62 \%), Mikania micrantha (12,08\%), Paspalum conjugatum P.J. Bergius (11,54 \%), dan Limnophila erecta $(10,57 \%)$. Di daerah tengah adalah Ageratum conyzoides (L) $(10,29 \%)$ dan di daerah hilir adalah Cyperus difformis (L) (20,34 \%), Eichornia crassipes (18,97 \%), Cynodon dactylon (14,48 \%), dan Ipomoea triloba $(11,72 \%)$. Hasil analisis vegetasi menunjukkan bahwa gulma Drymaria cordata (L) lebih mendominasi daerah bagian hulu DAS Cikeruh dan Cikapundung dibandingkan gulma yang lain. Menurut Soerjani (1980), gulma D. cordata (L) dapat tumbuh di tempat yang tersinari matahari maupun di tempat yang teduh, selain itu gulma D. cordata (L) mempunyai daya adaptasi dan kompetisi yang tinggi sehingga dapat mendomi- 
Tabel 3. Hasil Analisis Vegetasi Gulma di DAS Cikeruh dan Sungai Cikapundung.

\begin{tabular}{|c|c|c|c|c|c|c|c|}
\hline \multirow{2}{*}{ No. } & \multirow{2}{*}{ Jenis gulma } & \multicolumn{3}{|c|}{ SDR (\%) DAS Cikeruh } & \multicolumn{3}{|c|}{ SDR (\%) DAS Cikapundung } \\
\hline & & Hulu & Tengah & Hilir & Hulu & Tengah & Hilir \\
\hline 1 & Synedrella nodiflora $(L)$ & 2,39 & 3,84 & - & 0,99 & - & - \\
\hline 2 & Mimosa pudica $(L)$ & 1,30 & 4,30 & 2.7 & - & 5,08 & - \\
\hline 3 & Mikania micrantha Kunth. & 4,57 & 3,68 & - & 12,08 & - & - \\
\hline 4 & Commelina diffusa (Burm.f.) & 4,25 & 1,71 & - & 7,74 & - & - \\
\hline 5 & Elephantopus carolinianus Raeusch. & 3,01 & - & - & - & - & - \\
\hline 6 & Alternanthera philoxeroides (Mart.) & 6,04 & 6,14 & 12.23 & 7,93 & 3,26 & - \\
\hline 7 & Stachytarpheta jamaicensis $(L)$ & 2,11 & 2,21 & - & - & - & - \\
\hline 8 & Ageratum conyzoides $(L)$ & 2,11 & 6,51 & 3.54 & 5,91 & 10,29 & 5,36 \\
\hline 9 & Erigeron sumatrensis Retz. & 1,30 & - & - & - & - & - \\
\hline 10 & Asystasia gangetica $(L)$ & 4,41 & - & - & - & - & - \\
\hline 11 & Clidemia hirta $(L)$ & 2,37 & - & - & - & - & - \\
\hline 12 & Drymaria cordata $(L)$ & 11,51 & - & - & 12,62 & 6,89 & - \\
\hline 13 & Hyptis capitata Jacq. & 5,36 & - & 3.39 & - & - & - \\
\hline 14 & Pteridophyta sp & 2,23 & - & - & 6,51 & - & - \\
\hline 15 & Centella asiatica $(L)$ & 1,30 & - & - & - & - & - \\
\hline 16 & Amaranthus viridis $(L)$ & - & 4,86 & 11.26 & - & 7,44 & - \\
\hline 17 & Euphorbia hirta (L) & - & 10,51 & - & - & - & - \\
\hline 18 & Sida rhombifolia (L) & - & 2,41 & - & - & - & - \\
\hline 19 & Sonchus arvensis $(L)$ & - & 3,37 & 2.49 & - & 1,58 & - \\
\hline 20 & Monochoria vaginalis (Burm.f.) & 11,12 & 3,82 & - & - & - & - \\
\hline 21 & Thunbergia alata Bojer ex & - & 1,97 & - & - & - & - \\
\hline 22 & Celosia argentea $(L)$ & - & 1,45 & - & - & - & - \\
\hline 23 & Ludwigia perennis $(L)$ & 11,35 & 3,53 & 4.58 & - & 6,62 & 6,74 \\
\hline 24 & Phyllanthus debilis Klein ex Wild. & - & 1,97 & 1.91 & - & 2,39 & - \\
\hline 25 & Dichrocephala integrifolia $(L)$ & - & 1,21 & - & - & - & - \\
\hline 26 & Orthosiphon aristatus (Blume) Miq. & - & 1,21 & - & - & - & - \\
\hline 27 & Polygonum barbatum $(L)$ & - & 1,64 & - & - & - & - \\
\hline 28 & Eleutheranthera ruderalis (Sw.) & - & 0,77 & - & - & - & - \\
\hline 29 & Physalis angulata $(L)$ & - & 1,21 & - & - & - & - \\
\hline 30 & Lindernia.sp & - & - & 2.73 & - & - & - \\
\hline 31 & Bidens pilosa $(L)$ & - & - & 1.33 & - & - & - \\
\hline 32 & Amaranthus spinosus $(L)$ & - & - & 0.87 & - & 3,01 & 7,27 \\
\hline 33 & Richardia brasiliensis (Moq.) & - & - & 2.46 & - & - & - \\
\hline 34 & Cleome rutidosperma DC. & - & - & 5.99 & - & 2,44 & - \\
\hline 35 & Cynodon dactylon $(L)$ & 4,30 & 5,86 & 1.79 & - & 2,72 & 14,48 \\
\hline 36 & Paspalum conjugatum P.J. Bergius & 3,09 & - & - & 11,54 & - & - \\
\hline 37 & Aeschynomene indica $(L)$ & 2,58 & - & - & - & - & - \\
\hline 38 & Setaria palmifolia (J. Koenig) & 1,30 & - & 2.28 & - & 3,60 & - \\
\hline 39 & Panicum repens $(L)$ & 4,73 & 4,86 & 4.58 & - & - & 6,74 \\
\hline 40 & Brachiaria plantaginea (Link) Hitchc & - & - & - & - & 4,14 & - \\
\hline 41 & Leersia hexandra (Sw.) & 4,06 & - & 6.13 & - & - & - \\
\hline 42 & Limnophila erecta Benth. & - & 1,64 & - & 10,57 & - & - \\
\hline 43 & Eleusine indica $(L)$ & - & 12,37 & 17,19 & - & 8,50 & 8,36 \\
\hline 44 & Setaria palmifolia (J. Koenig) & - & 2,49 & - & - & - & - \\
\hline 45 & Digitaria sanguinalis $(L)$ & - & - & 3.54 & 5,35 & - & - \\
\hline 46 & Axonopus compressus (Sw.) & - & - & 2.49 & 5,13 & - & - \\
\hline 47 & Fimbristylis acicularis R.Br. & - & 3,02 & 4.67 & - & - & - \\
\hline 48 & Cyperus difformis $(L)$ & - & 1,45 & - & - & - & 20,34 \\
\hline 49 & Cyperus kyllingia Endl. & - & - & 1.64 & - & - & - \\
\hline 50 & Acmella paniculata (Wall. Ex DC) & - & - & - & 6,55 & - & - \\
\hline 51 & Amaranthus gracilis Desf. Ex Poir & - & - & - & 3,09 & - & - \\
\hline 52 & Lantana camara $(L)$ & - & - & - & 1,53 & - & - \\
\hline 53 & Oxalis oregano (R. Knuth) & - & - & - & 2,46 & - & - \\
\hline 54 & Eichornia crassipes (Mart.) & - & - & - & - & 8,50 & 18,97 \\
\hline 55 & Borreria alata (Aubl.) & - & - & - & - & 2,72 & - \\
\hline 56 & Tridax procumbens (L) & - & - & - & - & 7,83 & - \\
\hline 57 & Polygala paniculata $(L)$ & - & - & - & - & 4,36 & - \\
\hline 58 & Oxalis corniculata $(L)$ & - & - & - & - & 2,17 & - \\
\hline 59 & Eupatorium odoratum (L) & - & - & - & - & 4,14 & - \\
\hline 60 & Ipomoea triloba $(L)$ & - & - & - & - & - & 11,72 \\
\hline \multirow[t]{2}{*}{61} & Cyperus rotundus $(L)$ & - & - & - & - & 2,32 & - \\
\hline & JUMLAH & 100 & 100 & 100 & 100 & 100 & 100 \\
\hline
\end{tabular}


Tabel 4. Bobot Kering Gulma Dominan, Gulma Total, dan Gulma Lain di DAS Cikeruh dan Cikapundung.

\begin{tabular}{|c|c|c|c|c|c|c|c|}
\hline \multirow[t]{2}{*}{ No. } & \multirow[t]{2}{*}{ Jenis } & \multicolumn{3}{|c|}{ Bobot Gulma (g) di DAS Cikeruh } & \multicolumn{3}{|c|}{$\begin{array}{l}\text { Bobot Gulma (g) di DAS } \\
\text { Cikapundung }\end{array}$} \\
\hline & & Hulu & Tengah & Hilir & Hulu & Tengah & Hilir \\
\hline 1 & Monochoria vaginalis (Burm.f.) & 16,8 & - & - & - & - & - \\
\hline 2 & Ludwigia perennis $(L)$ & 42,9 & - & - & - & - & - \\
\hline 3 & Drymaria cordata $(L)$ & 28,8 & - & - & 10,1 & - & - \\
\hline 4 & Eleusine indica (L) & - & 46,69 & 80,7 & - & - & - \\
\hline 5 & Euphorbia hirta (L) & - & 79,1 & - & - & - & - \\
\hline 6 & Alternanthera philoxeroides (Mart.) & - & - & 19,1 & - & - & - \\
\hline 7 & Amaranthus piridis $(L)$ & - & - & 36,4 & - & - & - \\
\hline 8 & Mikania micrantha (Kunth) & - & - & - & 18,4 & - & - \\
\hline 9 & Paspalum conjugatum P.J. Bergius & - & - & - & 13,2 & - & - \\
\hline 10 & Limnophila erecta Benth. & - & - & - & 13,9 & - & - \\
\hline 11 & Ageratum conyzoides (L) & - & - & - & - & 32,5 & - \\
\hline 12 & Eichornia crassipes (Mart.) & - & - & - & - & - & 57,4 \\
\hline 13 & Cynodon dactylon $(L)$ & - & - & - & - & - & 53,4 \\
\hline 14 & Ipomoea triloba $(L)$ & - & - & - & - & - & 41,1 \\
\hline \multirow[t]{4}{*}{15} & Cyperus difformis $(L)$ & - & - & - & - & - & 35,8 \\
\hline & Gulma dominan & 88,5 & 125,79 & 136,2 & 55,6 & 32,5 & 187,7 \\
\hline & Gulma lain & 180,4 & 159,43 & 76,1 & 48,3 & 209,3 & 45,1 \\
\hline & Gulma total & 240,1 & 285,22 & 212,3 & 103,8 & 241,8 & 232,8 \\
\hline
\end{tabular}

nasi gulma-gulma lain. Faktor kualitas air juga sangat mempengaruhi pertumbuhan suatu gulma. Menurut Kurniadie (2003), semakin baik kualitas air maka semakin banyak gulma tumbuh, namun semakin buruk kualitas air maka semakin sedikit gulma tumbuh. Sastroutomo (1990) menyatakan bahwa, kepekaan gulma air untuk bertahan hidup berbeda-beda tergantung dengan kondisi kualitas suatu perairan.

Jenis gulma yang ditemukan di daerah industri (hilir) sungai Cikapundung lebih sedikit dibandingkan dengan daerah lain, hal ini mengidikasikan buruknya lingkungan kualitas air di daerah ini. Dilihat dari Tabel 1 dan 2, terbukti daerah hilir lebih keruh dibandingkan kualitas air di daerah pertanian dan pemukiman (hulu dan tengah, pernyataan ini didukung oleh Pujiastuti, dkk. (2013) bahwa kekeruhan perairan umumnya disebabkan oleh adanya partikelpartikel suspensi seperti tanah liat, lumpur, bahan-bahan organik terlarut, bakteri, plankton, dan organisme lainnya. Kekeruhan mempengaruhi penetrasi cahaya matahari yang masuk ke badan perairan, sehingga dapat menghalangi proses fotosintesis dan produksi primer perairan. Perairan daerah hilir sungai Cikapundung juga sudah mengalami pendangkalan sehingga tidak banyak gulma perairan yang ditemukan, melainkan banyaknya gulma daratan di sekitar perairan daerah hilir sungai Cikapundung.
Bobot Kering Gulma. Berdasarkan Tabel 4, menunjukkan bahwa di DAS Cikeruh hasil bobot kering (g) gulma dominan daerah bagian hulu, tengah, dan hilir berbeda. Di daerah tengah dan hilir ditemukan gulma Eleusine indica (L). Gulma E. indica (L) bukan merupakan gulma air atau perairan, hal ini diduga karena daerah tersebut sudah mengalami pendangkalan, sehingga jenis gulma yang banyak ditemukan adalah jenis gulma darat. Di DAS Cikapundung jenis gulma dominan yang terdapat di hulu, tengah, dan hilir sungai Cikapundung lebih beragam dan bervariasi dibandingkan dengan jenis gulma yang ditemukan di DAS Cikeruh, hal ini diduga karena kondisi abiotik seperti kualitas air, suhu, dan iklim pada tiap daerah perairan berbedabeda, sehingga hanya gulma tertentu saja yang mampu hidup dan beradaptasi pada lingkungan buangan limbah tersebut.

Koefisien Komunitas (C). Menurut Tabel 4. Nilai koefisien komunitas (C) yang diperoleh, dari ke-dua lokasi tersebut masing-masing sebesar 34,79\%,41,17\%, dan 23,85\%, nilai ini dapat diartikan terdapat perbedaan populasi. Sesuai dengan pendapat Tjitrosoedirdjo (1984), bahwa apabila nilai C lebih besar dari $75 \%$, maka diantara daerah tersebut memiliki kesamaan populasi yang cukup besar, namun apabila nilai C lebih kecil dari 75 \% maka daerah tersebut tidak terdapat kesamaan populasi. 
Tabel 5. Nilai Perbandingan Koefisien Komunitas (C) di DAS Cikeruh dan Cikapundung.

\begin{tabular}{cc}
\hline \hline Daerah Pembanding & Hasil C (\%) \\
\hline IA : IB & 34,79 \\
IIA : IIB & 41,17 \\
IIIA : IIIB & 23,85 \\
\hline \hline
\end{tabular}

Keterangan : I = Hulu, II = Tengah, III = Hilir A = Sungai Cikeruh, B = Sungai Cikapundung

Tabel 6. Indeks Keragaman Spesies Gulma ( $\left.\mathbf{H}^{\prime}\right)$ di DAS Cikeruh dan Cikapundung.

\begin{tabular}{lc}
\hline \multicolumn{1}{c}{ Lokasi } & $\begin{array}{c}\text { Komponen } \\
\text { Pengamatan } \mathrm{H}^{\prime}\end{array}$ \\
\hline Hulu DAS Cikeruh & 1,17 \\
Tengah DAS Cikeruh & 1,22 \\
Hilir DAS Cikeruh & 1,06 \\
Hulu DAS Cikapundung & 1,03 \\
Tengah DAS Cikapundung & 1,20 \\
Hilir DAS Cikapundung & 0,90 \\
\hline \hline
\end{tabular}

Indeks Keragaman Spesies Gulma $\left(\mathrm{H}^{\prime}\right)$. Dilihat dari hasil Indeks keragaman Spesies $\left(\mathrm{H}^{\prime}\right)$ Tabel 6, diketahui bahwa keragaman gulma yang muncul di setiap daerah bagian DAS Cikeruh dan Cikapundung rata-rata menunjukkan hasil pada rentang 1-2, nilai ini termasuk ke dalam kategori rendah. Katagori ini sesuai dengan yang dikemukakan oleh Agustina (2008), jika $\mathrm{H}^{\prime}<1$ maka termasuk kategori keragaman sangat rendah, jika $\mathrm{H}^{\prime}>1-2$ termasuk kategori rendah, jika $\mathrm{H}^{\prime}>2-3$ termasuk kategori sedang, jika $\mathrm{H}^{\prime}>$ 3-4 termasuk kategori tinggi, danjika $\mathrm{H}^{\prime}>4$ termasuk kategori sangat tinggi.

Nilai keragaman spesies gulma $\left(\mathrm{H}^{\prime}\right)$ terkecil terdapat pada daerah hilir DAS Cikapundung, hal ini didukung oleh hasil analisa kualitas air (Tabel 1) yang menunjukkan bahwa nilai $\mathrm{BOD}_{5}$ dan COD tinggi, merupakan ciri kualitas air buruk dan tercemar, sehingga gulma tidak dapat beradaptasi untuk tumbuh dan berkembang pada lingkungan tersebut. Kondisi ini didukung pula oleh data pada parameter lainnya. Odum (1996) dalam Mawazin dan Subiakto (2013), menyatakan bahwa keragaman jenis gulma $\left(\mathrm{H}^{\prime}\right)$ dalam komunitas semakin stabil, jika nilai $\mathrm{H}^{\prime}$ semakin tinggi., sebaliknya tingkat kestabilan keragaman jenis gulma dalam komunitas semakin rendah jika nilai $\left(\mathrm{H}^{\prime}\right)$ rendah. Dengan demikian nampak bahwa di DAS Cikapundung daerah hilir keragaman jenis gulma dalam komunitas tidak stabil

Menurut Kurnia, (2009) menyatakan bahwa kualitas suatu perairan yang bersih, dapat ditentukan oleh tiga parameter utama yaitu : Oksigen Terlarut (DO), $\mathrm{BOD}_{5}$ (Biological Oxygen Demand), dan COD (Chemical Oxygen Demand)

Korelasi Keragaman Gulma dengan Kualitas Air. Berdasarkan analisis statistik, korelasi antara keragaman gulma dengan kualitas air (Tabel 7) menunjukkan bahwa tidak terdapat korelasi atau hubungan antara keragaman gulma dengan kualitas air DAS Cikeruh dan DAS Cikapundung. Semakin baik kualitas air, maka semakin banyak gulma yang tumbuh, dan begitu juga sebaliknya. Hal ini juga didukung oleh pendapat Sastroutomo (1990) bahwa, keberadaan gulma ditiap DAS berbeda-beda dipengaruhi oleh keadaan kondisi air disekitar tempat gulma tumbuh tersebut. Gulma akan tumbuh dengan baik apabila kondisi perairannya baik, namun apabila kondisi perairan buruk maka pertumbuhan gulma akan terhambat. Tidak terjadinya korelasi kemungkinan disebabkan oleh faktor lingkungan sekitar perairan yang berubah-ubah, Penelitian dilakukan saat musim hujan hal ini mungkin dapat menyebabkan terjadinya pengenceran konsentrasi zat terlarut pada air sungai yang tidak stabil. Pendapat ini didukung oleh Sastrawijaya (1991) yang menyatakan bahwa unsur kualitas air saling berkaitan antara satu dengan yang lainnya, faktor lingkungan lain yang mendukung seperti topografi, sumber pencemar, dan berbagai kondisi lain nya dapat mempengaruhi kualitas air suatu perairan.

\section{Kesimpulan}

Keragaman jenis gulma pada DAS Cikapundung berbeda dengan jenis gulma di sungai Cikeruh. Gulma dominan yang terdapat di DAS Cikeruh bagian hulu adalah Drymaria cordata

Tabel 7. Nilai Korelasi Keragaman Gulma dengan Kualitas Air.

\begin{tabular}{lcccccc}
\hline \hline \multirow{2}{*}{ Keragaman Gulma } & \multicolumn{2}{c}{ BOD } & \multicolumn{2}{c}{ COD } & \multicolumn{2}{c}{ DO } \\
\cline { 2 - 7 } & $\mathrm{R}$ & $\mathrm{p}$ & $\mathrm{r}$ & $\mathrm{p}$ & $\mathrm{r}$ & $\mathrm{p}$ \\
\hline ASDAS Cikeruh & $0,741 \mathrm{~ns}$ & 0,46 & $0,741 \mathrm{~ns}$ & 0,46 & $-0,610 \mathrm{~ns}$ & 0,58 \\
DAS Cikapundung & $-0,843 \mathrm{~ns}$ & 0,36 & $-0,847 \mathrm{~ns}$ & 0,35 & $0,996 \mathrm{~ns}$ & 0,06 \\
\hline \hline
\end{tabular}

Keterangan $: \mathrm{r}=$ nilai korelasi, $\mathrm{p}=$ angka signifikansi, $\mathrm{ns}=$ non signifikan. 
(11,51 \%), Monochoria vaginalis $(11,12 \%)$, dan Ludwigia perennis $(11,35 \%)$. Gulma dominan daerah tengah DAS Cikeruh adalah Eleusine indica $(12,37 \%)$, dan Euphorbia hirta (10,51 \%), gulma dominan daerah hilir sungai Cikeruh adalah Eleusine indica (17,19 \%), Alternanthera philoxeroides $(12,23 \%)$, dan Amaranthus piridis $(11,26 \%)$. Sedangkan gulma dominan yang terdapat di bagian hulu DAS Cikapundung adalah Drymaria cordata (12,62 \%), Mikania micrantha (12,08 \%), Paspalum conjugatum (11,54\%), dan Limnophila erecta $(10,57 \%)$, gulma dominan daerah tengah DAS Cikapundung adalah Ageratum conyzoides L $(10,29 \%)$, serta gulma dominan yang ditemukan di daerah hilir DAS Cikapundung adalah Cyperus difformis $(20,34 \%)$, Echornia crassipes $(18,97 \%)$, Cynodon dactilon (14,48 \%), dan Ipomoea triloba $(11,72 \%)$. DAS Cikeruh dan Cikapundung memiliki perbedaan populasi yang cukup besar, tetapi memiliki Indeks keragaman Spesies $\left(\mathrm{H}^{\prime}\right)$ gulma yang muncul di setiap daerah bagian DAS Cikeruh dan Cikapundung rata-rata menunjukkan hasil pada rentang 1-2, nilai ini termasuk ke dalam kategori rendah. Nilai keragaman spesies gulma terkecil terdapat pada daerah hilir DAS Cikapundung, hal ini didukung oleh hasil analisa kualitas air yang menunjukkan bahwa nilai $\mathrm{BOD}_{5}$ dan COD tinggi, merupakan ciri kualitas air buruk dan tercemar, sehingga gulma tidak dapat beradaptasi untuk tumbuh dan berkembang pada lingkungan tersebut. Semakin baik kualitas air, maka semakin banyak gulma yang tumbuh, dan begitu juga sebaliknya.

\section{Daftar Pustaka}

Agustina, D.K. 2008. Studi Vegetasi Pohon di Hutan Lindung RPH Donomulyo, BKPH
Sengguruh KPH Malang.http://repository. usu.ac.id. (diakses : 15 September 2014).

Bisri, M. 2009. Pengelolaan Daerah Aliran Sungai. Asrori. Malang. $220 \mathrm{hlm}$.

Edward, A. 1981. Aquatic Pollution. John Willey and Sons. New York. 482 pages.

Halim. 2010. Pengelolaan Gulma : Biologi, Klassifikasi, dan Pengendaliannya. Unpad Press. $129 \mathrm{hlm}$.

Happy, A. R; Masyamsir; Dhahiyat, Y. 2012. Distribusi Kandungan Logam Berat $\mathrm{Pb}$ dan Cd Pada Kolam Air dan Sedimen Daerah Aliran Sungai Citarum Hulu. Jurnal Perikanan dan Kelautan 3 (3) : 175-182.

Kurnia, A. 2009. Parameter Pengolahan Air Limbah Industri. http://majarimagazine. com/. (Diakses tanggal 6 Oktober 2014).

Mawazin dan A. Subiakto. 2013. Keanekaragaman dan Komposisi Jenis Permudaan Alam Hutan Rawa Gambut Bekas Tebangan di Riau. http://forda-mof.org (Diakses tanggal 9 Agustus 2014).

Matahelumual, C.B. 2010. Kajian Kualitas Air Sungai Sebagai Sumber Air Baku PDAM (Sungai Citarum dan Sungai Cikapundung). Buletin Geologi Tata Lingkungan (Bulletin of Environmental Geology) 20 (1) : 1-12.

Pujiastuti, P., I. Bagus, dan Pranoto. 2013. Kualitas dan Beban Pencemaran Perairan Waduk Gajah Mungkur. Jurnal Ekosains 5 (1) : 59-75.

Sastroutomo, S. Soetikno. 1990. Ekologi Gulma. Penerbit PT Gramedia Pustaka Utama. Jakarta.

Suripin. 2002. Pengelolaan Sumber Daya Tanah dan Air. Penerbit Andi. Yogyakarta. $210 \mathrm{hlm}$.

Tjitrosoedirdjo, Soekisman, Utomo Is Hidayat \& Wiroatmodjo, J. 1984. Pengelolaan Gulma di Perkebunan. PT. Gramedia Jakarta. 209 hlm. 